\title{
Students' Reference Mastery in Narrative Text at XI Grade of Senior High School
}

\author{
Dahliana $^{1}$, Muhammad Zaim ${ }^{1}$ \\ ${ }^{1}$ Universitas Negeri Padang \\ ${ }^{1}$ Email: dahlianaanahata@gmail.com \\ 2Email:mzaim_unp@yahoo.com
}

\begin{abstract}
Reference is an essential component for comprehending a reading text. In comprehending a text some students had problem such as their limited vocabulary, inability to interpret reference, and lack of background knowledge. The purpose of the research was to find out the students' reference mastery in narrative text and students' difficulties in mastering reference. This research was a descriptive research. Random sampling technique was applied and twenty two students of XI grade of SMAN 1 Tempuling were taken as the subject of the research. The data were collected through quantitative and qualitative methods. Reading test was distributed to collect quantitative data, while interview was applied to gather qualitative data. The findings of this research reveal that the students' reference mastery was in good category, but some problems still appeared which were affected by some factors; lack of practice, limited vocabulary mastery, and poor grammar mastery. Thus, it can be concluded that the students' reference mastery in narrative text needed to be improved.
\end{abstract}

Keywords: Reference, Mastery, Narrative Text

\begin{abstract}
Abstrak
Referensi adalah komponen penting dalam memahami bahan bacaan. Dalam memahami sebuah teks, siswa mengalami kesulitan seperti keterbatasan kosa kata, tidak mampu menafsirkan referensi, dan kekurangan pengetahuan umum. Tujuan penelitian ini adalah untuk menemukan kemampuan siswa dalam menguasai referensi dan menemukan kesulitankesulitan yang dihadapi siswa dalam menguasai referensi. Penelitian ini merupakan penelitian deskriptif. Random sampling teknik digunakan dalam pengambian sample dan dua puluh dua siswa kelas XI SMAN 1 Tempuling terpilih menjadi sample penelitian. Data dikumpulkan melalui metode kuantitatif dan kualitatif. Test pemahaman bacaan digunakan untuk mengumpulkan kuantitatif, sedangkan wawancara diadakan untuk mendapatkan data kualitatif. Hasil penelitian ini menunjukkan bahwa penguasaan reference siswa dikategorikan baik, akan tetapi beberapa kesulitan masih muncul yang disebabkan oleh beberapa faktor, seperti kurang latihan, terbatasnya penguasaan kosa kata, dan kurangnya penguasaan tata bahasa. Jadi, dapat disimpulkan bahwa penguasaan reference siswa masih perlu ditingkatkan lagi.
\end{abstract}

Kata Kunci: Reference, Penguasaan, Teks Naratif 


\section{INTRODUCTION}

Reference is an essential component for comprehending a reading text. It is the association of a word or expression with the object it refers to (Fromkin, Rodman, and Hyams, 2011:194). It is very useful in interpreting some words or phrases by relating to other words or phrases to be understood. Reference helps students to get information from the text well. So, their knowledge will increase as there is much information available in a text.

Reference is a term for a word or expressions which should be related to other words or expression for its meaning. Yule (2003:204) defined reference as the relationship of reference is taken to hold between expression in a text and entities in the world, and reference between expressions in different parts of a text". Furthermore, Hurford and Heasly (2007: 26) said that reference as the relationship between language and the world. From their statements, it can be simplified that the interpretation of words or expressions of reference are related closely with the readers' knowledge of the world.

Reference is taught integrately with other component of reading. There are five components of reading which is commonly taught to students. They are finding factual information, finding main idea, finding the meaning of vocabulary in context, identifying reference, and making inference (King and Stanly, 1997). All of the components cannot be separated in the process of reading because they support each other to make a sense of a reading text. Reference occurs in every type of reading text. One of them is narrative text. Rebecca (2003:147) said that a narrative text is a text which relates a series of event logically, and chronologically. The story makes point or explains an idea. It relates to a sequence of event often in the form of the story. Then, Emmot (cited in Maspufah, 2015:2) claims that narrative is succession of events where some or all of the events are described as they take place within a particular contexts. It can be inferred that narrative is a kind of text that tell about a story which contains orientation, complication, and resolution which are organized in a series of event to entertain or amuse the reader.

Reference is classified into three types: personal, comparative, and demostrative reference (Halliday and Hasan, 2011:33). Personal reference is the reference that exists in the speech situation in which occured in the form of personal pronoun. Demonstrative reference is concerned with the action of being grabbing. It means that the distance is relative from the speaker or writer. Comparative reference is indirect reference which compared the existence of two things from likeness or unlikeness, equal or unequal, more or less. To find out the students' reference mastery, three classification of reference as proposed by Halliday and Hasan (2011: 33) used as the indicator of the test. Halliday and Hasan's types are chosen because it is explained in detail and in specific way. Besides that Halliday and Hasan were the experts in the field of functional grammar and discourse analysis which their theory was deeper than others.

In narrative text, reference is used to link the idea between one sentence to the other and also between a paragraph to another. Moreover, it is not only a device to make narrtive texts smooth to read, but also help the reader to understand the the plot of the story. Based on the writer experience during teaching English in grade XI SMAN 1 Tempuling, the researcher found that most of students got low score in reading narrative text, even below the KKM (75). They were suffering from low score in 
reading narrative text because of several problems. First, most of students of grade XI IPA 1 SMAN 1 Tempuling had limited vocabulary to understand narrative text. They are confused whenever they find new words in the text. Furthermore, some of English vocabulary has similar meaning. As the result, they misinterpret some words which lead them to misunderstanding the plot in the story.

Second, most of students were confused to interpret references in narrative text which did not have their own meaning, but it should be related to other words. They also got difficulties to find the words which it was referred to, especially the words which should be referred forward in the text. So, they did not comprehend the narrative text well.

Third, they had lack of background knowledge of reading topic that they were assigned to read. They did not have sufficient understanding to predict and guess the content of the story. This condition made them unable to get the main message conveyed in the narrative text well. In other words, the students did not activate their background knowledge and try to relate them with the new information. In narrative text, there were some words or phrases which cannot be interpreted directly, but it should be related to other words or phrases to get their meaning. Those words were called as reference. However, most of the students at grade of XI SMAN 1 Tempuling were seemed unable to interpret reference well. Therefore, they had problems in understanding narrative text.

It is necessary to conduct a research to find out the students' reference mastery on narrative text at eleventh year students of 2012/ 2013 of Tempuling Senior High School. The narrative text is chosen for this research because it is taught in every grade of SMA level, especially in grade of XI IPA 1 where this research was conducted.

Based on the previous explanation, the purposes of this research were; to find out the students' mastery on reference, and the difficulties faced by students in mastering reference.

\section{METHOD}

This research was conducted through descriptive design which was intended to find out the students' reference mastery on narrative text. Best cited in Maspufah (2018: 74) said that descriptive research describes the situation or thing that exists at the same time of the study. It means that this research did not tend to find a new theory rather than to verify and describe the students' reference mastery on narrative text. By applying quantitative approach, it attempted to find out the students' reference mastery on narrative text.

The population of the study was the eleventh year students of 2013/ 2014 of Tempuling Senior High School. It is located on Jalan 21 Maret Pangkalan, Sungai Salak. There are four parallel classes which were divided into two major sections, namely Natural Science Section (Ilmu Pengetahuan Alam: IPA) and Social Science Section (Ilmu Pengetahuan Sosial: IPS). Each section consisted of two parallel classes; IPA 1, IPA 2, IPS 1, and IPS 2 with a total number of 111 students. This research used clustering random sampling technique. Random sampling technique was applied due to four parallel classes which had the equal chances to be selected to be the sample and. Clustering system was appropriate to apply to all students in one class to manage their time in following the research procedure. Lottery system was applied and 25 of XI IPA 1 students of 
2012/ 2013 of Tempuling Senior High School.

In this study, there were two instruments used to collect the data. The quantitative data were obtained from reading test and the quantitative data were obtained from interview.

In collecting the data, the tests were administered twice with different questions to get a more accurate data of students' reference mastery. After the students' answer were scored, interview was conducted to them who got low score in doing the test.

The quantitative data were analyzed by scoring the test, determining the standard of competence based on their minimum achievement criteria that was 80 , counting the mean score, then compared with the standard of level mastery in order to determine the level of the students' reference mastery in narrative text. The qualitative data were analyzed by reducing the data, displaying the table, and drawing a conclusion.

\section{FINDING AND DISCUSSION}

\subsection{Students' Mastery on Reference}

There are three types of reference which are used as indicator of the test in this research. The students' mastery on each type of reference was explained as the following:

\subsubsection{The Students' Reference Mastery in Personal Reference}

Personal reference occured in the form of personal pronoun possessive determiner/ possessive adjectives, and possessive pronoun. From the data description, it was found that the students' mastery on personal reference was good. It can be seen in table 1:
Table 1. The Students' Mastery on Personal Reference

\begin{tabular}{|c|c|c|c|}
\hline Score & $\begin{array}{c}\text { Number } \\
\text { of } \\
\text { Student }\end{array}$ & Percentage & Category \\
\hline $80-100$ & 7 & $31 \%$ & $\begin{array}{c}\text { Very } \\
\text { Good }\end{array}$ \\
\hline $60-79$ & 13 & $59 \%$ & Good \\
\hline $40-59$ & 2 & $10 \%$ & Fair \\
\hline $0-39$ & - & - & Poor \\
\hline
\end{tabular}

The students' reference mastery on personal reference was in good category. Some students got problem in mastering personal reference which its interpretation refers forward or cataphora in the text. They got confused and made mistake. Based on the interview, it was revealed that they seldom find this kind of question before. In other words, students had lack of practice such question. In this case, the teacher should provide more various questions. to their students in teaching and learning reading, because reference can be referred forward or backward in the text (Halliday, 2011: 46). For example :

(1) Text: "He had not expected to meet the lady of his dreams, but there Rosa was strolling along in the moonlight. Carlos quickened his pace until he was level with her, hoping for a glimpse of her face under the veil. The next day dragged by the infatuated Carlos, and he had trouble concentrating on his work. Carlos was absolutely useless at work and to his boss. After work, he rushed home and found a letter in his mailbox. Then he ran next door to show it to Diego and Marco, his closest cousin" 
Question: The word he in the first sentence refers to.
a. Diego
b. Carlos
c. The boss
d. Marco
e. Rosa

A large number of the students got problem to identify the personal reference which is not stated clearly in the text. They got problem to find the character and lexically interpret. This condition affected the students' ability to recognize the character in the narrative text.

(2) Text: "The question is: should we Tell aunty Gwen about Mum?

Gwen remembers how it was after Dad died. Mum sitting with her knees splayed apart on the sofa. 'Good God, Marge,' she said, pulling Mum's skirt down. She won't know her with the nurses making such a fuss of her. 'Your mother's dropped her bundle"

Question: The word we in the first sentence refers to
a. Gwen and Marge
b. Nurses
c. Marge's children
d. Marge and Nurses
e. Gwen and Marge's children

\subsubsection{Students' Reference Mastery in Demonstrative Reference}

Demonstrative reference is reference which consist of demonstrative pronoun and its pluralism. From the test, it was found out that their mastery in good category. Their level of mastery can be seen in table 2 :
Table 2. The Students' mastery of Demonstrative Reference

\begin{tabular}{|c|c|c|c|}
\hline Score & $\begin{array}{c}\text { Number } \\
\text { of } \\
\text { Student }\end{array}$ & Percentage & Category \\
\hline $80-100$ & 12 & $54 \%$ & Very Good \\
\hline $60-79$ & 8 & $36 \%$ & Good \\
\hline $40-59$ & 2 & $10 \%$ & Fair \\
\hline $0-39$ & - & - & Poor \\
\hline
\end{tabular}

Demonstrative reference includes all the words of indicating or pointing. The students' reference mastery in demonstrative reference was good. Some students had limited vocabulary which made them could not find the referent word. Without sufficient vocabulary mastery, the students were suffer in comprehending the text. Limited vocabulary also made some students were confused to find demonstrative reference which its' interpretation should be related to the previous information to get the clue. Without sufficient vocabulary, the students showed inability to use linguistics cues in the large context to draw meaning and recognize lexical relationship and meaning relationship between sentences (Alderson, 2000:56). For example:

(3) Text : "The Sheep thought the Lion wanted to know the truth. So she said, 'Your Majesty, your breath smells terrible. This was not what the Lion had wanted to hear. Roaring angrily and bit her head off. The Wolf had seen the dead Sheep on the way, and he had no plans to end up the same way and said "Your breath smells as sweet as the flowers in spring" "Liar!' roared the Lion, and ripped him to pieces. The Fox came warily; she had seen the dead 
Sheep and the dead Wolf on the way. 'The Fox coughed and sneezed and blew her nose and whisper, 'Your Majesty, forgive me. I have such a nasty cold that I cannot smell a thing!'

Question: The word this refers to

a. Lion's bad breath smell

b. Wolf' lies

c. Lion's good breadth smell

d. The fox's cold

e. Lioness' bad smell

Some students also seemed lack of motivation in reading comprehension as well as interpreting demonstrative reference in a large context It was proven in interview that they only saw their friends' answer. If this habit keep continouing, their mastery in reading comprehension would not improved, because motivation of learning has been considered as the key of concept of learning foreign language (Klimova, 2011:15).

\subsubsection{Student's Reference Mastery in Comparative Reference}

Comparative reference consists of comparison, identity, similarity, difference, quantity, and quality. From the test, it was found out that their mastery was in good category. Their level of mastery can be seen in table 3 :

Table 3. The Students' mastery of Comparative Reference

\begin{tabular}{|c|c|c|c|}
\hline Score & $\begin{array}{r}\text { Number of } \\
\text { Student }\end{array}$ & Percentage & Category \\
\hline $80-100$ & 5 & $22 \%$ & $\begin{array}{c}\text { Very } \\
\text { good }\end{array}$ \\
\hline $60-79$ & 14 & $64 \%$ & Good \\
\hline $40-59$ & 3 & $14 \%$ & fair \\
\hline $0-39$ & - & - & Poor \\
\hline
\end{tabular}

The students' reference mastery in comparative reference in narrative text was good. They had problems in mastering comparative reference. This was caused by their understanding of grammar is low, especially about the tenses used. They were confused to identify the change form of verb in every tenses, especially the irregular verb such as "catch - caught -caught". Actually, their understanding of tenses is crucial because most of narrative were written in past form (Choo, Ling, and Smith, 2003:32).

Furthermore, they not only failed to recognize the change of irregular verb, but also the compasionatte such as other, others, another, etc. For example:

(4) Text : When it reached Bukit BatuPatah, the army commander said to the leaders of Alam, "You had better surrender The king of Java is very strong. Otherwise we shall attack your country and kill many of your people."'To fight is easy," replied the wise men of Alam, "but who knows who will win? Why should we kill each other? Let's find a better way.""Very well," said the army commander. "What do you sug $\neg$ gest?""Let us each bring a buffalo to fight. Your buffalo can fight with ours. If your buffalo wins, then we shall surrender to the king of Java. If our buffalo wins, then we shall continue to be free."“"Excellent," Said the army commander.

Question: . . .Why should we kill each other..? What does the underlined word refer to?

a. King of alam

b. Leader of ala people of alam

c. people of minang

d. people of Sembilan

Some students were unable to see the context to understand the story. Again, their limited vocabulary did not support their comprehension to sense the tone of the story which creates the atmosphere of the 
story. Limited vocabulary also made them not competent to link the referent word with the previous information to interpret the meaning. They tried to comprehend the text through each word translation without considering the context found within the text.

(5) Text : He stayed away a whole year, and then came back one day, dragging one foot after the other, and a poor wizened face on him, and he as cross as two sticks. When he was rested and got something to eat, he told them how he got service with the Gray Churl of the Townland of Mischance, and that the agreement was, whoever would first say he was sorry for his bargain, should get an inch wide of the skin of his back, from shoulder to hips, taken off.

Question: .... dragging one foot after the other, and a poor wizened.

What does the closest meaning of underlined word?
a. Bad
b. That it
c. Good
d. Worse
e. Not bad

From all the data, students' mastery on personal, demonstrative, and comparative was in good category. It can be concluded that students' mastery on reference was in good level. It was indicated by the majority of students' achievement were ranging between $60-79$ or in good category.

\subsection{Students' Difficulties in Mastering Reference}

Generally, it can be inferred that the students' problems in mastering reference were because of limited knowledge of language, limited vocabulary, and low motivation toward reading. In spite of those which had been put in the indicators of problems in mastering reference in narrative text, one problem occurred that was lack of practice. Besides that, types of question given did not affect or become a problem for them.

\subsubsection{Language problem}

Some of students have problems in understanding grammar or structure which are used in narrative text. Most of them had problem to comprehend the meaning of almost whole sentences in the text since they lack of grammar, especially in past tense and compassionate. It seemed they were not focus while they were learning a structure or the media were not interesting for them. So, the instructions were meaningless and they did not record it in their mind. The teachers could check the students' understanding of what they have studied by monitoring the use of grammar in both spoken or written.

The teachers could also check the use of past tense to talk about an event in the past. It could be check whether the students understood by constructing the sentences referred to the past, present or future. Another way to help to understand the meaning of a structure is to provide a background situation. The situation can be introduced in a variety of ways including using pictures, a dialogues, a short text and real object (Lindsay and Knight, 2006: 56). Therefore, in teaching structure, English teachers needed to be more creative to use various media and teaching method. Teachers should realize that learning structure is more difficulT than learning vocabulary, while teaching grammar only occupied a little portion as a language feature integrated with reading comprehension. In addition, it is important for the teachers to know as much as possible about the language that they are 
teaching. The language system is complex and needed to be guided to learn it.

Researcher: What types of reference which is the most difficult for you? What difficulties do you face in mastering reference?

Student 20: Personal reference mam, It spends much time because I need to read over and over again to find its interpretation. I have tried to see the meaning in the dictionary but the meaning is not matched. The grammar also the big problem with me to understand the story.

\subsubsection{Knowledge of Vocabulary}

There are some factors which can help the reader to master reference in narrative. One of them is vocabulary. Alderson (2000:56) says that without sufficient lexical knowledge, the readers show inability to use linguistics cues in the large context in order to draw meaning and to recognize lexical relationship and meaning relationship between sentences. It means that if the students lack of vocabulary will fail to draw the meaning from the text.

To get better comprehension of a text, the students not only need sufficient vocabulary knowledge but also good reading skills. It was proven when they try to comprehend the demonstrative and comparative reference from the text through each word translation without considering the context found within the text. They tend to interpret the same words as the same meaning. While, in reference the same words could be refers to other persons. .

Vocabulary knowledge and reading skills are important to gain a better comprehension of a text. one of reading skills that is often used is to guess meaning from context. However most of eleventh grade of SMAN 1 Tempuling said that they were unable to answer the questions since they could not understand the text and difficult words found in the text although they have tried to guess their meaning from its context. This happened because they had limited vocabulary.

Researcher : What types of reference which is the most difficult for you? What difficulties do you face in mastering reference?

Siswa 7 : Comparative mam. The meaning cannot be seen in dictionary. So, I just see my friends' answer

Student 20 : Personal reference Ma'am, it is difficult to find which is the character. Sometimes, it is not stated explicitly. We are seldom given the question which its' answers do not stated clearly and we have to find the meaning again in dictionary

\subsubsection{Motivation}

Students had low motivation in reading as they say that they saw their friends' answer. Other student said that he was lazy to read such a long reading material. It is believed that the students had lack of vocabulary, so that they have difficulties to figure out the meaning of words even sentences. Their vocabulary is very poor because they seldom to use it in daily activity. Besides that the students had low motivation to improve their vocabulary because the way the teacher in teaching vocabulary might not interesting and effective one.

Student 3 : Comparative reference mam. It is difficult to find its' word mam, sometimes it refers forward and backward. Moreover, the words which refers forward because we seldom find such question like this before

Student 5 : All of them mam. When I see the text, I am getting lazy to do the test. The texts are too long.

From several statements, it can be concluded that the difficulties faced by students in mastering reference were (1) they seldom find it in the test before or in 
other words they were lack of practice this kinds of reference given such question by their teacher. (2) they had limited vocabulary and lack of motivation. (3) Their problems were also caused by their low understanding of grammar, especially in the uses of tenses and compassionate.

To solve these problems Teachers are expected to explain more about types of reference to avoid confusion whenever they found referent words in a text, because a sentence may has more than one types of referent. Besides that the teachers are expected to try their best to increase their students' vocabulary, understanding of grammar, and also motivation so that they can gain a much deeper understanding on reference especially in narrative texts. Teachers also have to provide a lot of exercise with various types of questions and discuss it together with the students in order to show how to use context, as the clue to master reference.

\section{CONCLUSION}

Based on the findings and discussion, it could be concluded that the students' mastery on reference was good. It was indicated that most of students score was in good category. Some problems still appeared which were affected by some factors; lack of practice, limited vocabulary mastery, and poor grammar mastery.

\section{REFERENCES}

Alderson, J. C. 2000. Assessing reading. Cambridge Cambridge University Press.

Choo, L.J, Ling, J, and Smith, A. 2003. My Pals are Here $4 B$. Singapore : Singapore Times International Printing.
Fromkin, V, Rodman, R and Hyams, N. 2011. An Introduction to Language $\left(9^{\text {th }}\right.$ edition). Boston: Michael Rosenbery.

Halliday, M.A.K and Hasan, R. 2011. Cohesion in English. London: Longman.

Hurford, J and Heasly, B. 2007. Semantics; A Course Book (2nd Edition). New York: Cambridge.

King, L and Stanley, G. 1997. Third Grade Reading Comprehension Series. Retrieved on Dec 3rd, 2012 from http://printables.familyeducation.com/bo tr/botr book.html?pid+tv0012

Klimova, B. F. 2011. Motivation for learning English at a university level. Procedia. Social and Behavioral Sciences, Vol 15 Retrieved at June 25th 2013 from http://dx.doi.org/10.1016/ j.sbspro.2011.04.153

Lindsay, C. and Knight, P. 2006. Learning and Teaching English: A Course for Teacher. London: Oxford

Maspufah, 2018. Analysis of Discourse Deixis in EFL Learners of STIBA Persada Bunda. ELT-Lectura, Vol 5 No.1:72-77 https://doi.org/10.31849/eltlectura.v5i1.1534

Rebecca, J.L. 2003. A Critical Handbook of Children's Literature. Massachuset: Pearson Education Inc.

Yule, G. 2003. Pragmatics. Oxford: $O x$. 